\title{
Habitat preferences of common native fishes in a tropical river in Southeastern Brazil
}

\author{
Marcus Rodrigues da Costa ${ }^{1,2}$, Tailan Moretti Mattos ${ }^{2}$, Joyce Liz Borges ${ }^{2}$ \\ and Francisco Gerson Araújo ${ }^{2}$
}

We determined in this study the habitat preferences of seven native fish species in a regulated river in Southeastern Brazil. We tested the hypothesis that fishes differ in habitat preference and that they use stretches of the river differing in hydraulic characteristics and substrate type. We surveyed fishes in four 1-km long river stretches encompassing different habitat traits, where we also measured water depth, velocity, and substrate type. We investigated preference patterns of four Siluriformes (Loricariichthys castaneus, Hoplosternum littorale, Pimelodus maculatus, and Trachelyopterus striatulus) and three Characiformes (Astyanax aff. bimaculatus, Oligosarcus hepsetus, and Hoplias malabaricus), representing approximately $70 \%$ of the total number of fishes and $64 \%$ of the total biomass. We classified fishes into four habitat guilds: (1) a slow-flowing water guild that occupied mud-sand substrate, composed of two Siluriformes in either shallow $(<4 \mathrm{~m}$, i.e., H. littorale) or deep $(>$ $8 \mathrm{~m}$, L. castaneus) waters; (2) a run-dwelling guild that occurs in deep backwaters with clay-mud substrate, composed of the Characiformes $A$. aff. bimaculatus and $O$. hepsetus; (3) a run-dwelling guild that occurs in sandy and shallow substrate, composed of T. striatulus; and (4) a fast-flowing guild that occurs primarily along shorelines with shallow mud bottoms, composed of H. malabaricus and P. maculatus. Our hypothesis was confirmed, as different habitat preferences by fishes appear to occur in this regulated river.

Determinamos neste estudo a preferência de habitat de sete espécies de peixes abundantes em um rio regulado do Sudeste do Brasil. Testamos a hipótese de que peixes diferem na preferência de habitat e usam trechos do rio com diferentes características hidráulicas e tipos de substratos. Realizamos amostragens de peixes, utilizando redes de espera e tarrafas em quatro trechos do rio de $1 \mathrm{~km}$ de extensão, compreendendo diferentes características do habitat, onde também obtivemos medidas de profundidade, velocidade da água e tipo de substrato. Quatro Siluriformes (Loricariichthys castaneus, Hoplosternum littorale, Pimelodus maculatus e Trachelyopterus striatulus) e três Characiformes (Astyanax aff. bimaculatus, Oligosarcus hepsetus e Hoplias malabaricus) que juntos compreenderam aproximadamente $70 \%$ do número total e $64 \%$ do peso total de peixes foram estudados. Classificamos os peixes em quatro guildas: (1) peixes que ocorrem em trechos com baixa velocidade de fluxo e substrato constituído predominantemente de lama e areia, compreendendo dois Siluriformes, um de áreas rasas $(<4 \mathrm{~m}$, i.e., H. littorale) e outro de áreas profundas (> $8 \mathrm{~m}$, i.e., L. castaneus); (2) peixes que utilizam rápidos de áreas laterais mais profundas com substrato lamoso, representados pelos pequenos Characiformes, A. aff. bimaculatus e O. hepsetus; (3) peixes que utilizam rápidos que ocorrem em áreas rasas e substrato arenoso, representado por T. striatulus; e (4) peixes de corredeiras que utilizam as margens rasas com fundo lamoso, representados por H. malabaricus e P. maculatus. As espécies estudadas apresentam diferenciação na preferência por variáveis do hábitat, corroborando a hipótese investigada.

Key words: Ecological flow, Freshwater fishes, Habitat guild, River flow.

\section{Introduction}

The study of habitat preferences is an essential step in understanding the distribution patterns of fishes. Most knowledge of this subject is based on native nongame fish habitat preferences for temperate freshwaters (Moyle \& Baltz, 1985; Lamouroux et al., 1999; Vadas \& Orth, 2000, 2001; Boavida et al., 2006). However, with the exception of a few studies (e.g., Bührnheim, 2002; Leal et al., 2011; Teresa \& Casatti, 2013), little effort has been made to understand

\footnotetext{
${ }^{1}$ Centro Universitário Módulo, Av. Frei Pacífico Wagner, 653-Centro, 11660-903 Caraguatatuba, SP, Brazil.profmar@gmail.com
} ${ }^{2}$ Universidade Federal Rural do Rio de Janeiro, Laboratório de Ecologia de Peixes, Km 7, BR-465, 23.890-000 Seropédica, RJ, Brazil. 
habitat preferences by fish in tropical rivers. Instream habitat preferences are often used to assess flow requirements for fish, usually based on instream flow incremental methodology (IFIM; Bovee, 1982). The habitat component of IFIM (PHABSIM; Milhous et al., 1984) predicts water depths and velocities for instream cells and evaluates the suitability of the habitat for a species over a range of flows. Once the habitat suitability or preference curves are defined, they can be applied to hydraulic data, and the amount of suitable habitat or weighted useable area (WUA) can be calculated.

Habitat heterogeneity in lotic environments generally influences fish assemblage distributions, generally downstream, increasing as lateral and vertical profiles are enhanced via increased off-channel habitat complexity and water volume (Pinto et al., 2006; Terra et al., 2010). Several environmental variables are preferentially selected by fish species in these ecosystems (Bovee, 1982; Baltz et al., 1987; Yu \& Lee, 2002; Vadas \& Orth, $2000,2001)$. For instance, habitat availability affects selection by fish species, with the majority of habitat-preference models based on individual factors such as depth, velocity, substrate, and type of cover (Sheppard \& Johnson, 1985; Leonard \& Orth, 1988).

Reductions in river flow may result in a loss of critical habitat for fish (Petts, 1985). In this context, habitat analysis simulations, such as PHABSIM (Milhous et al., 1989) and RHYHABSIM (Jowett, 1989), can be used to define requirements for minimum instream flow requirements that must be maintained to preserve the fish fauna (Bovee, 1982). However, the use of these simulations depends on the creation of habitat suitability criteria that define the use of physical habitat variables by fish species. Furthermore, suitability criteria are important because they most likely have more influence on habitat/flow relationships than any other part of the habitat modeling process (Jowett, 2002). Depending on the selected target species, suitability patterns can be extended to other systems to allow the construction of predictive models at large scales (Teresa \& Casatti, 2013).

The definition of fish habitat preferences may serve to improve the ability to evaluate the biological consequences of anthropogenic impacts on aquatic ecosystems, helping environmental managers establish policies for river resource conservation at local and regional scales. Local departures from natural conditions can occur, especially if there is longitudinal and/or lateral blockage of the lotic system by damming and channelization. Historically, such perturbations have been associated with impoundments, primarily for hydroelectric power generation and water supply (Petts, 1984). Most large rivers in Southeastern Brazil are regulated by some type of impoundment. A notable instance is the Guandu River, a regulated system that supplies water to the municipality of Rio de Janeiro. This system has been subject to several forms of interference, such as interbasin water transfer and impoundments, which have altered its natural flow regime (CBH - Guandu, 2007).
Although there is a clear consensus that modified flow regimes in regulated rivers are affecting fishes and fish habitat, the severity and direction of the response varies widely (Murchie et al., 2008). The Guandu River represents a good opportunity for the study of fish habitat preferences. Accordingly, the aim of this study was to describe habitat suitability for the dominant fish species in the Guandu River. We assessed fish occurrence and measured three physical variables: depth, water velocity, and type of substrate. We sampled four 1-km long river stretches encompassing different mesohabitats, surveying two stretches upstream from the impoundment and two downstream. We tested the hypothesis that fish preferences for a given habitat stretch differ depending on local differences in water velocity, depth, and type of substrate.

\section{Material and Methods}

\section{Study area}

The Guandu River (Fig. 1) is a regulated system with a watershed area of $1,430 \mathrm{~km}^{2}$. It is formed by the confluence of the Lajes and Santana streams, with an extension of $c a$. 108.5 $\mathrm{km}$ and an average flow of $156 \mathrm{~m}^{3} \mathrm{~s}^{-1}$ above the dam (Table 1). The principal contribution of water to the river is made by an interbasin transfer from the Paraíba do Sul River basin since 1952. An electric company pumps water for hydropower purposes, releasing a water discharge of $c a .160 \mathrm{~m}^{3} \mathrm{~s}^{-1}$ into Lajes stream (Binder, 1998). The river is impounded $30 \mathrm{~km}$ upstream from the estuary at $11.8 \mathrm{~m}$ above sea level. From this impoundment, $c a$. $47 \mathrm{~m}^{3} \mathrm{~s}^{-1}$ are withdrawn to supply tap water for the municipality of Rio de Janeiro and nearby areas, thus decreasing the river flow in the mid-lower segment (CBH - Guandu, 2007). The river is channelized above the estuarine zone.

\section{Sampling}

We conducted fish sampling and environmental measurements in four 1-km long river stretches in two (winter/ dry and summer/wet) seasons during two years (2010 and 2011). Seven evenly spaced longitudinal sections were established as the sampling sites along each $1-\mathrm{km}$ river stretch. Each river stretch encompassed different mesohabitats, such as runs, riffles, and pools (Table 1). The sampling design comprised a total of 112 samples ( 2 seasons $\times 2$ years $\times 4$ stretches $\times 7$ sections).

The sampling unit used in each section consisted of three nets $(25 \mathrm{~m} \times 2.5 \mathrm{~m}$ height; stretch-mesh sizes of 2.5, 5.0, and $7.5 \mathrm{~mm}$ ), covering an area of $\sim 187.5 \mathrm{~m}^{2}$. We set up the nets at the end of the afternoon and retrieved them the following morning for a total sampling time of $c a$. 15 hours. A total of 21 nets were used in each river stretch to cover the seven locations (transversal sections). During each sampling visit, 


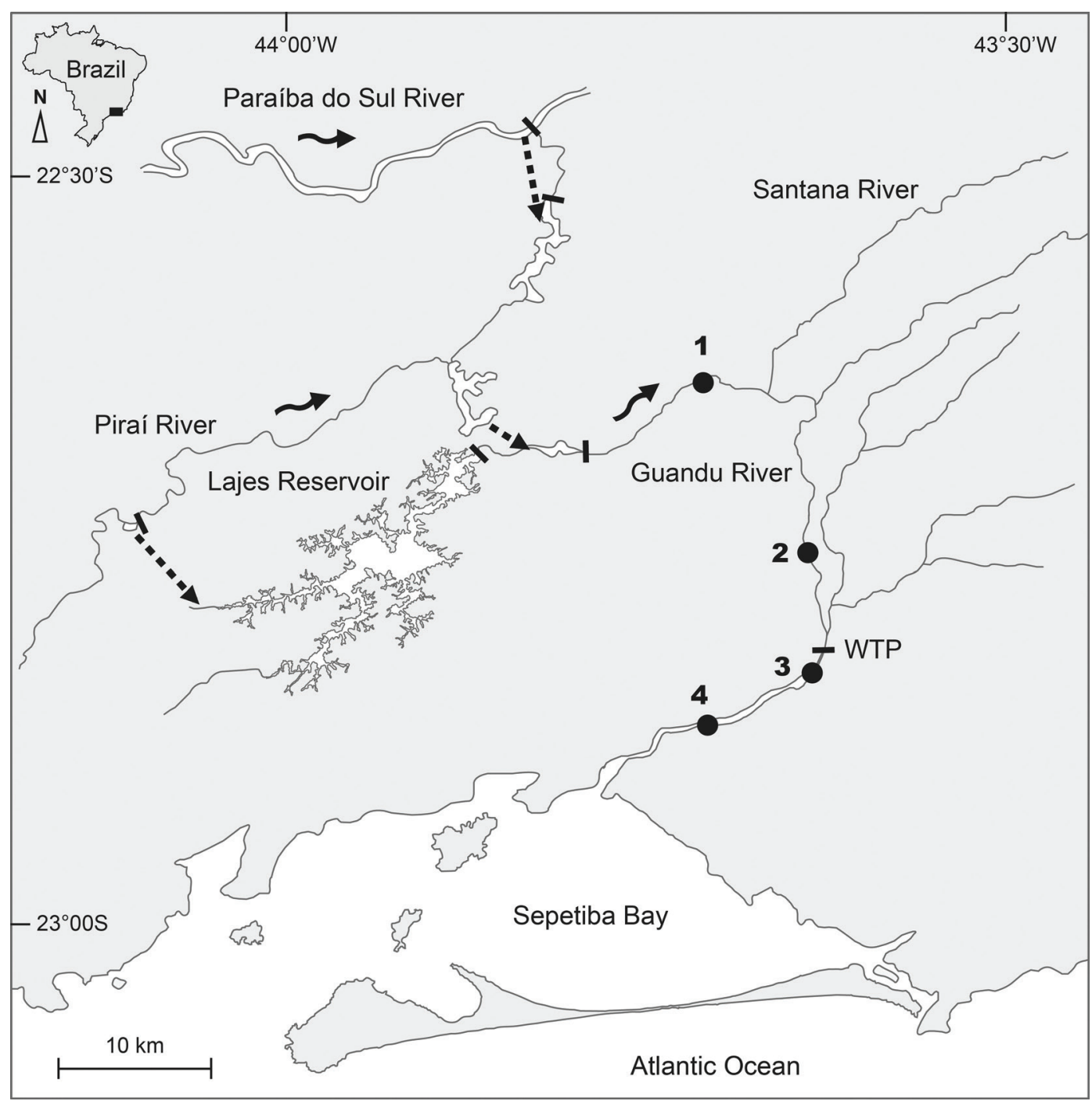

Fig. 1. Study area, Guandu River, indicating the four sampled stretches. WTP, Water Treatment Plant.

Table 1. Physical characteristics of the four sampled river stretches.

\begin{tabular}{|c|c|c|c|c|c|c|c|c|c|}
\hline $\begin{array}{l}\text { River } \\
\text { stretch }\end{array}$ & $\begin{array}{c}\text { Dominant } \\
\text { Mesohabitat type }\end{array}$ & $\begin{array}{c}\text { Substrate } \\
(\%)\end{array}$ & Width (m) & $\begin{array}{c}\text { Depth } \\
\text { range (m) }\end{array}$ & $\begin{array}{l}\text { Altitude } \\
\text { (m) }\end{array}$ & $\begin{array}{l}\text { Average Flow } \\
\text { (m3 sec-1) }\end{array}$ & Land use & $\begin{array}{c}\text { Riparian } \\
\text { Cover (\%) }\end{array}$ & Erosion \\
\hline \multirow[t]{5}{*}{1} & Run & Sand (50) & 105.5 & $1.5-3.5$ & 32.9 & 137.7 & Pasture & Trees & Moderate \\
\hline & & Gravel (20) & & & & & & Shrubs & \\
\hline & & Mud (15) & & & & & & Grasses & \\
\hline & & Clay (10) & & & & & & & \\
\hline & & Rock (5) & & & & & & & \\
\hline \multirow[t]{2}{*}{2} & Backwater & Sand (60) & 110.0 & $4.7-10.1$ & 12.6 & 156.3 & Agriculture & Shrubs & Moderate \\
\hline & & Mud (40) & & & & & & Grasses & \\
\hline \multirow[t]{4}{*}{3} & Fast flowing & Sand (60) & 87.5 & $3.3-8.1$ & 8.1 & 111.7 & Urban area & Shrubs & High \\
\hline & & Mud (20) & & & & & & Grasses & \\
\hline & & Rock (10) & & & & & & & \\
\hline & & Boulder(10) & & & & & & & \\
\hline \multirow[t]{2}{*}{4} & Moderate flow & Mud (70) & 69.0 & $3.9-6.9$ & 6.3 & 167.4 & & Grasses & High \\
\hline & & Sand (30) & & & & & & & \\
\hline
\end{tabular}


we measured the following habitat traits in triplicate: depth, with a portable echo-sounder; water velocity, with a Global Waters FP-211 flow meter (Global Water Instrumentation, Inc. College Station, TX, USA); and type of substrate, determined visually. The fishes collected were measured (total length, $\mathrm{mm}$ ), weighed (grams), and fixed in $10 \%$ formalin. After 48 hours, we transferred all fishes to $70 \%$ ethanol. Voucher specimens are deposited in the fish collection of the Laboratory of Fish Ecology of the Universidade Federal Rural do Rio de Janeiro (UFRRJ-LEP 1001-1007).

\section{Data analysis}

Because the numerical abundance of the fish did not differ seasonally or between the two study years based on exploratory data analysis with a Kruskal-Wallis test, we pooled the data from years and seasons to detect habitat use. We defined the dominant species in a given river stretch as those species that included more than 20 individuals and that occurred in more than $35 \%$ of the samples.

For the analysis of habitat use, fish occurrence and habitat data were used only from sites where the species was present. Microhabitat use was determined by the frequency at which a given species was observed using specific depths, velocities, and substrate type. For this calculation, microhabitat measurements were weighted by the number of fish in each class. We divided the number of fishes into habitat classes based on intervals of depth, velocity, and substrate size. The percentage fish-use of each habitat class was defined as the average fish number in that class expressed as a percentage of the sum of the average fish numbers over all habitat classes:

$$
\mathrm{Pi}=\left(N_{\underline{\underline{i}}} / \sum N_{\mathrm{i}}\right) \times 100, \quad i=1, \mathrm{n},
$$

where $P i=$ percentage fish-use in habitat class $i, N_{\mathrm{i}}=$ average fish number in habitat class $i$ over all sites, and $n=$ the number of habitat classes.

Microhabitat preference curves were derived by comparing the frequency of habitat use (in which fishes were found) with the frequency in which habitat was available (sampled) for each habitat class. We calculated preference as the normalized ratio of the frequency of use to the frequency of availability determined from the ordinates of kernel smoothed frequency curves (Bovee, 1986; DeGraaf \& Bain, 1986; Hayes \& Jowett, 1994; Jowett \& Richardson, 1995). Because we scaled the curves to a maximum preference value of 1 by dividing by the maximum ordinate, the suitability scale ranged from 0 (minimum suitability) to 1 (maximum suitability). Following Jowett (2002), we use the term 'habitat suitability criteria' to refer to curves developed from a subjective interpretation of habitat use and preference. All suitability curves were generated by the software HABPRF (Analysis of Habitat Suitability - version 2.0; Jowett, 2005).

\section{Results}

\section{Fish composition}

We recorded 50 species belonging to 20 families and six orders. Of these species, 31 were natives, five were non-natives, and 14 were marine. Siluriformes were prominent contributors to species richness (12), followed by Perciformes (11) and Characiformes (9). The seven most abundant native species, Loricariichthys castaneus (Castelnau, 1855), Hoplosternum littorale (Hancock, 1828), Pimelodus maculatus Lacepède, 1803, Trachelyopterus striatulus (Steindachner, 1877), Astyanax aff. bimaculatus (Linnaeus, 1758), Oligosarcus hepsetus (Cuvier, 1829), and Hoplias malabaricus (Bloch, 1794) contributed more than $70 \%$ of total fish numbers and $64 \%$ of total weight and collectively occurred in all of the habitat types observed.

\section{Habitat type}

The distribution and relative abundance of the seven examined fish species differed among river stretches (Table 2). The average abundance (fish numbers) was higher in the river stretch having a predominance of runs (upper stretch) than in the other stretches. In the upper stretch, A. aff. bimaculatus and $O$. hepsetus (Characiformes) and P. maculatus (Siluriformes) reached their highest abundance. The highest abundance of $L$. castaneus was recorded in the backwater stretch (middle-upper stretch); H. malabaricus was most abundant in the fast-flowing stretch (middle-lower stretch); and T. striatulus and H. littorale were most abundant in the moderate-flow lower stretches.

Table 2. Numbers of selected fish species collected in the four river stretches and their percent occurrence (in parentheses). Dominant species for each river stretch are boldfaced.

\begin{tabular}{lcccc}
\hline River stretches & Upper & $\begin{array}{c}\text { Middle- } \\
\text { upper }\end{array}$ & $\begin{array}{c}\text { Middle- } \\
\text { lower }\end{array}$ & Lower \\
\hline $\begin{array}{l}\text { Predominant } \\
\text { Mesohabitat }\end{array}$ & Run & Backwater & $\begin{array}{c}\text { Fast- } \\
\text { flowing }\end{array}$ & $\begin{array}{c}\text { Moderate- } \\
\text { flow }\end{array}$ \\
\hline $\begin{array}{l}\text { Astyanax } \\
\text { bimaculatus } \\
\text { Oligosarcus } \\
\text { hepsetus }\end{array}$ & $\mathbf{6 6}(\mathbf{4 5 . 2 )}$ & $\mathbf{6 0}(\mathbf{4 1 . 1 )}$ & $10(6.9)$ & $10(6.9)$ \\
$\begin{array}{l}\text { Hoplias } \\
\text { malabaricus }\end{array}$ & $\mathbf{2 2 ( 3 5 . 5 )}$ & $\mathbf{1 7}(\mathbf{2 9 . 8 )}$ & $3(5.3)$ & $9(15.8)$ \\
$\begin{array}{l}\text { Pimelodus } \\
\text { maculatus }\end{array}$ & $\mathbf{3 9}(\mathbf{6 6 . 1 )}$ & $12(20.3)$ & $4(6.8)$ & $4(6.8)$ \\
$\begin{array}{l}\text { Loricariichthys } \\
\text { castaneus }\end{array}$ & $26(4.8)$ & $\mathbf{2 6 0}(\mathbf{4 8 . 4 )}$ & $136(6.9)$ & $\mathbf{2 1 4}(\mathbf{3 9 . 9 )}$ \\
$\begin{array}{l}\text { Trachelyopterus } \\
\text { striatulus }\end{array}$ & $36(25.9)$ & $38(27.3)$ & $2(1.4)$ & $\mathbf{6 3}(\mathbf{4 5 . 3 )}$ \\
$\begin{array}{l}\text { Hoplosternum } \\
\text { littorale }\end{array}$ & $4(1.8)$ & $13(5.8)$ & $59(26.5)$ & $\mathbf{1 4 7}(\mathbf{6 5 . 9})$ \\
\hline \begin{tabular}{l} 
Total \\
\hline
\end{tabular} & $221(18.1)$ & $408(33.4)$ & $138(11.3)$ & $456(37.3)$ \\
\hline
\end{tabular}




\section{Habitat relationships}

The depth of the sampling units ranged from 0.4 to $9.7 \mathrm{~m}$, with the highest frequency of sampling units occurring in the shallowest waters (Fig. 2). The sampling frequency was not uniform over water depths because it was difficult to set up the fishing gear in mid-channel. The distribution of fish with water depth varied among species. Loricariichthys castaneus was dominant in deeper waters, whereas P. maculatus and T. striatulus occurred primarily in water $<4.0 \mathrm{~m}$ deep (Table 2 ).

Velocities in the sampling units ranged from 0 to $1.3 \mathrm{~m} \mathrm{~s}^{-1}$. More than half of the sampling habitat units had average velocities $<0.3 \mathrm{~m} \mathrm{~s}^{-1}$, and only $10 \%$ of the units had velocities in excess of $0.6 \mathrm{~m} \mathrm{~s}^{-1}$ (Fig. 2).

The substrate types ranged from clay to rocks, with a modal type of muddy and sandy substrate (Fig. 2). Three species, namely, $A$. aff. bimaculatus, $O$. hepsetus, and $P$. maculatus, were most abundant in sites with a diversified substrate, whereas $H$. malabaricus was most abundant in sites with mud and rock substrates and $L$. castaneus and T. striatulus were more abundant in sites with fine substrates (mud and clay) (Table 2).

\section{Habitat preference}

All fish species showed well-defined microhabitat preferences for depth, velocity, and type of substrate (Fig. 3). The optimum depths for the two species of Siluriformes ( $H$. littorale and $T$. striatulus) and the Characiformes species $H$. malabaricus were all less than $4 \mathrm{~m}$. However, the Characiformes species $A$. aff. bimaculatus and $O$. hepsetus and the Siluriformes species $L$. castaneus primarily used deeper water, with optimum depths at $>6 \mathrm{~m}$, whereas $P$. maculatus occupied a wider depth range.

The species presented well-defined velocity preferences. Loricariichthys castaneus and $H$. littorale occurred primarily mainly in the slowest-flowing water $\left(<0.6 \mathrm{~m} \mathrm{~s}^{-1}\right)$, whereas other species preferred more rapidly flowing water $\left(>0.8 \mathrm{~m} \mathrm{~s}^{-1}\right)$ (Fig. 4).

Substrate preferences were less well-defined, as most species used wide ranges of substrate types. Oligosarcus hepsetus, H. malabaricus, and P. maculatus preferred midsized substrates (Fig. 5); L. castaneus, H. littorale, and T. striatulus preferred coarser sand and gravel substrates; and A. aff. bimaculatus preferred the finest substrates, especially sand (Fig. 5).

\section{Discussion}

We found that the seven dominant Guandu River fish species had differentiated habitat preferences for a given water depth, velocity, and substrate type. These preferences appear to represent an adaptation for coexistence in this regulated system. The Characiformes $A$. aff. bimaculatus and $O$. hepsetus differed from the other five species; they
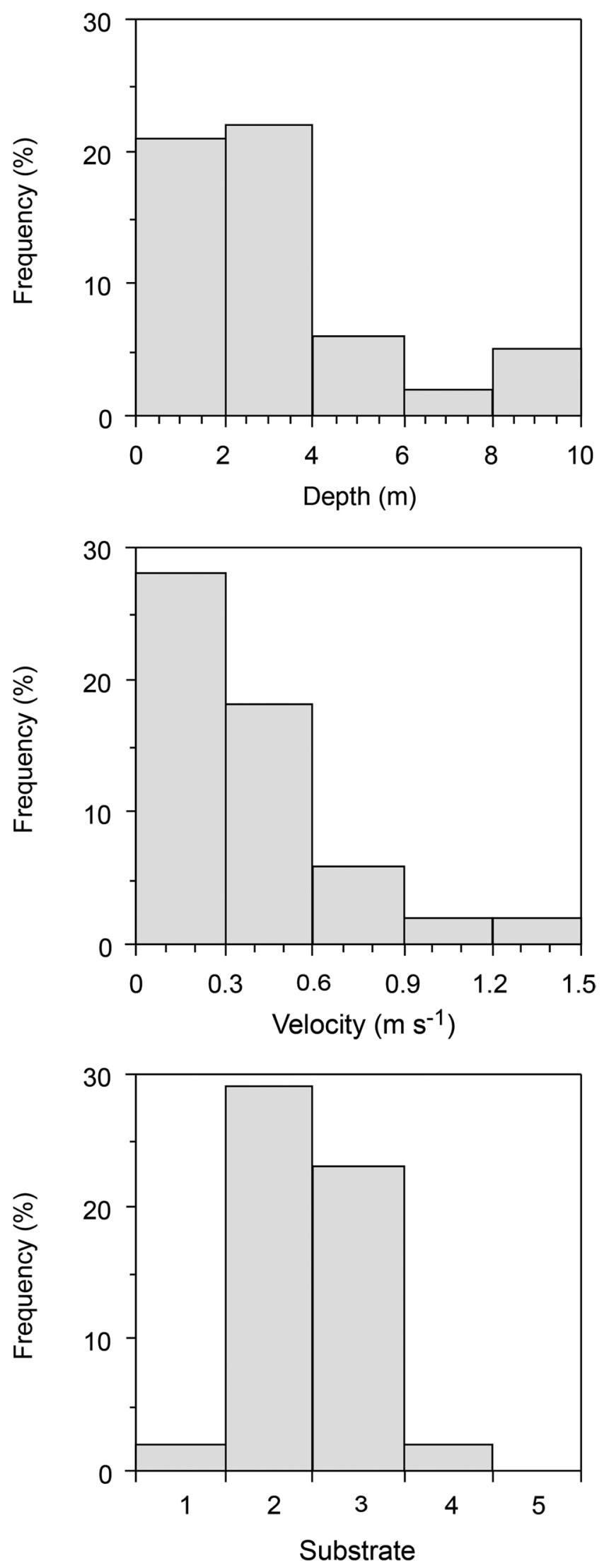

Fig. 2. Distribution of sampling by habitat availability (\%) in terms of depth $(\mathrm{m})$, velocity $\left(\mathrm{m} \mathrm{s}^{-1}\right)$, and type of substrate. (1, clay; 2 , mud; 3 , sand; 4 , boulder/cobble/gravel; 5 , bedrock). 
were the only water-column dwelling species that occurred across the entire habitat and occupied various substrate types. These species preferred the deepest areas (depth $>6 \mathrm{~m}$ ) but also used the margins, where they presumably fed on insects, leaf packs, and submerged roots. Astyanax spp. are prey for large, carnivorous species (Câmara et al., 1991), whereas $O$. hepsetus is a small carnivore that uses densely vegetated areas to prey on small fishes and insects (Araújo et al., 2005). Hoplias malabaricus is a highly unique characiform fish, differing from most other species within this order because it is a top carnivore and bottom dweller that ambushes its prey by hiding in shallow, high-velocity waters near rocky substrates (Oliveros \& Rossi, 1991).

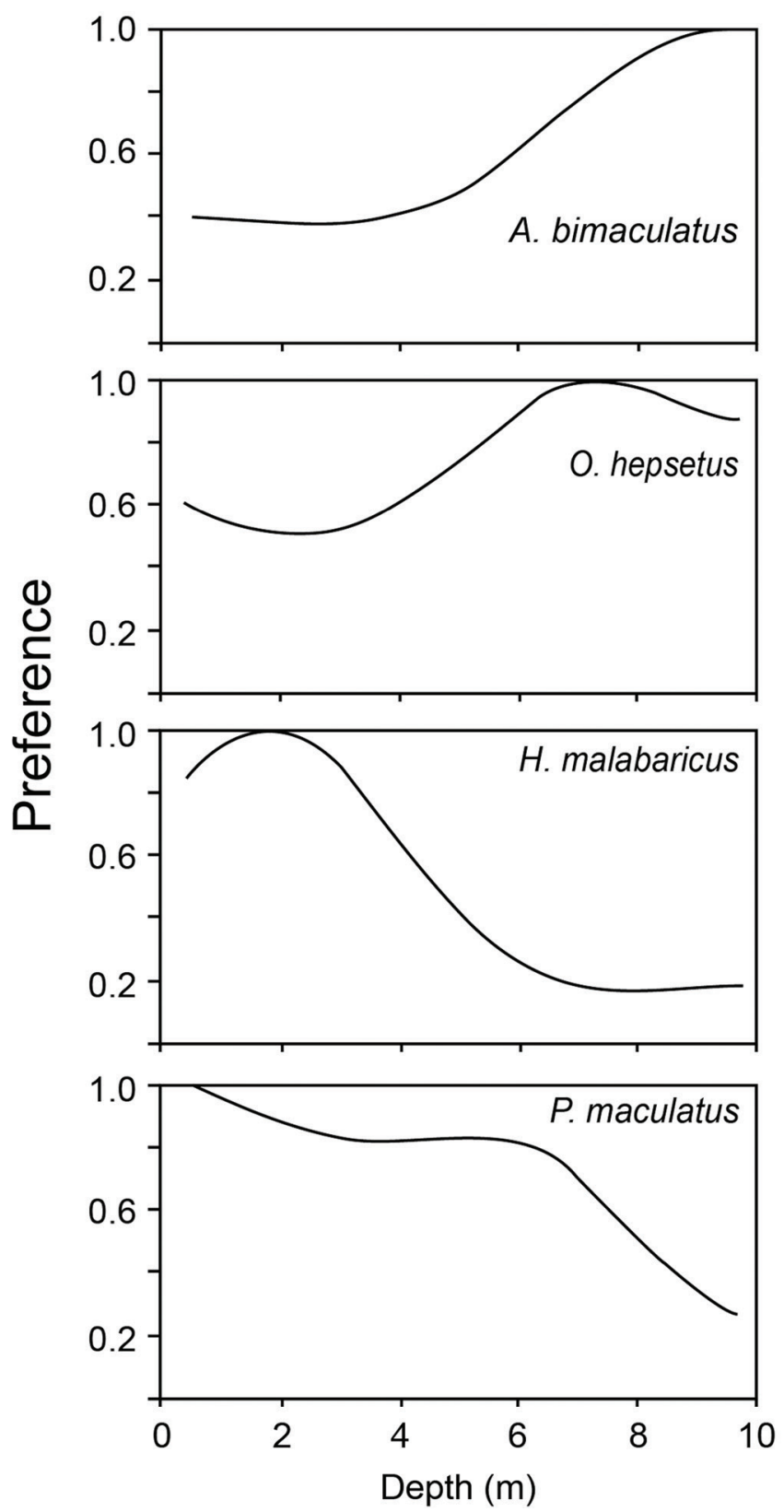

Astyanax aff. bimaculatus, O. hepsetus, and L. castaneus preferred areas deeper than $6 \mathrm{~m}$, whereas the other examined species preferred shallow areas. Similarly to T. striatulus and H. littorale, L. castaneus preferred slowly flowing waters in areas with sandy and gravel substrates, although the latter two species occurred primarily in shallow water (depth $<4 \mathrm{~m}$ ). These three Siluriformes are typical fishes of lentic or slow-moving systems (Suzuki et al., 2000; Duarte \& Araújo 2001; Santos et al., 2010) and were found in a wide range of microhabitats and aquatic systems, including reservoirs (Araújo \& Santos, 2001), shallow riverine zones (Santos et al., 2010; Terra et al., 2010), and floodplains (Hostache \& Mol, 1998).
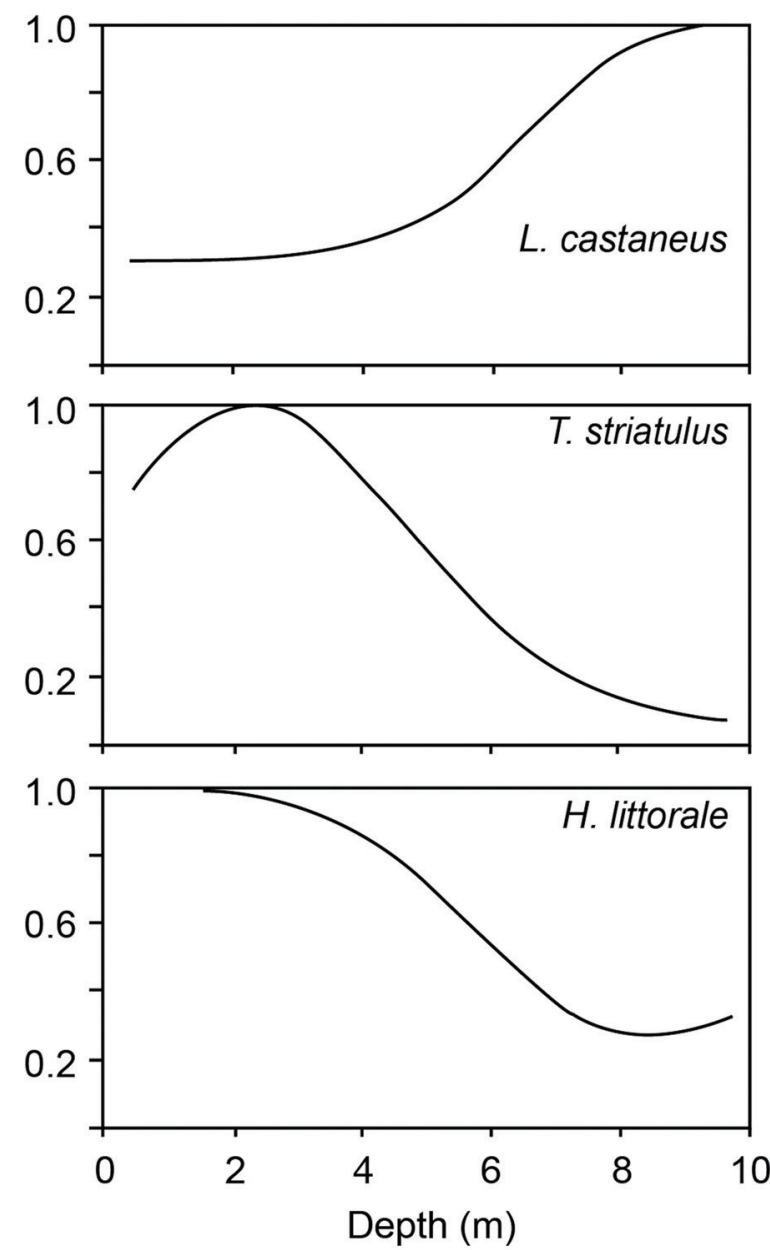

Fig. 3. Depth preferences of seven dominant native fish species in the Guandu River. 


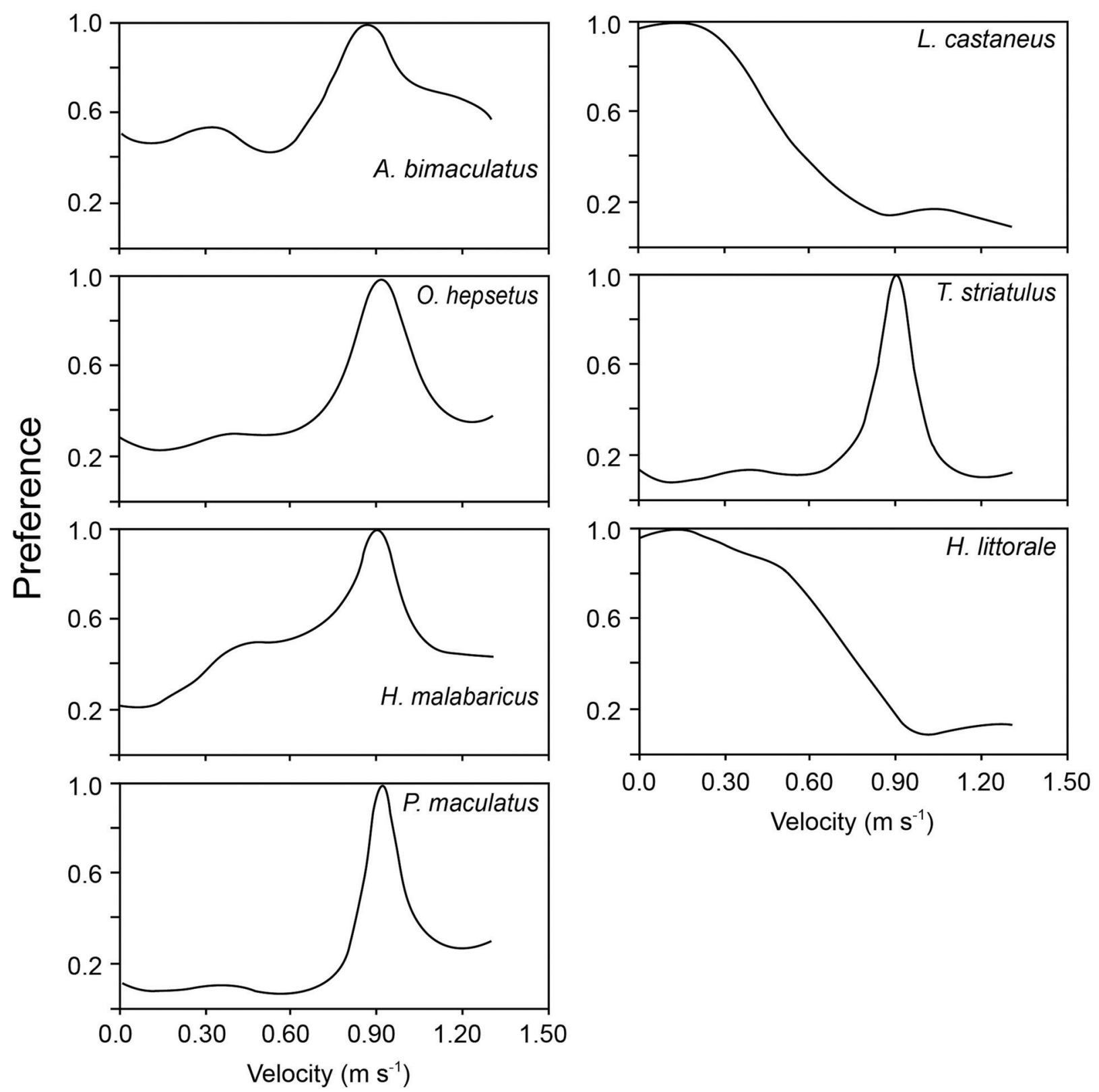

Fig. 4. Velocity preferences of seven dominant native fish species in the Guandu River.

Preferences for low or moderate velocity by $T$. striatulus, H. littorale, and L. castaneus depart from the general pattern described for Siluriformes, which generally prefer rapids and higher-velocity waters than Characiformes (Casatti et al., 2001; Casatti, 2005). However, Duarte \& Araújo (2001) found that $L$. castaneus is one of the most abundant fish species in Lajes Reservoir, confirming that this species shows great adaptive plasticity in habitat use. Trachelyopterus striatulus and $H$. littorale are benthic invertivores that predominate in lentic waters (Araújo \& Santos 2001) such as reservoirs, floodplains, and swamps (Hostache \& Mol, 1998). They were particularly common in the lower stretch of the Guandu River. Leal et al. (2011), studying morphology and habitat use by fishes in a tropical river, found that Siluriformes generally had morphological and behavioral adaptations to habitats with fast-moving waters and that they were found more frequently than Characiformes in microhabitats with greater water velocities. Most fishes examined by Leal et al. (2011) were smaller species that appeared to be particularly sensitive to water velocity. In our study, most fishes were medium-sized, and this difference in size structure could at least partially explain such differences. Furthermore, establishing patterns of habitat preferences for such rich and diverse groups of fishes as Characiformes and Siluriformes will never completely characterize the entire group of fishes for a given water body. 


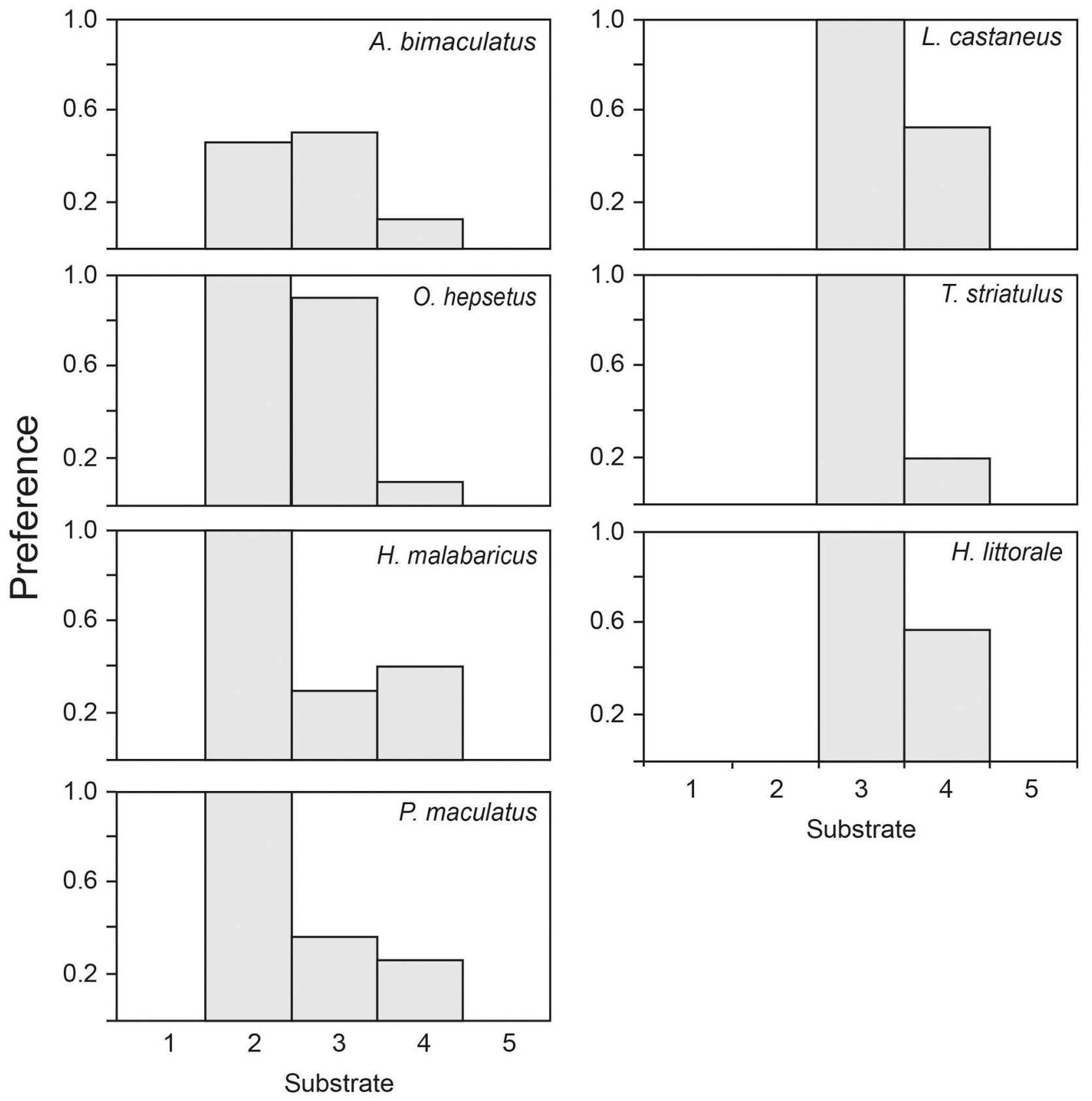

Fig. 5. Substrate preferences of seven dominant native fish species in the Guandu River. Type of Substrate: 1, clay; 2, mud; 3 , sand; 4, boulder/cobble/gravel; 5, bedrock.

Pimelodus maculatus is the only examined Siluriformes species with rheophilic habits. It performs upriver migrations, especially during the reproductive period (Vono et al., 2002). Because of its capacity to move among different habits, it used several types of substrate and was not confined to a narrow range of depth or water velocity. Santos et al. (2010) studied the effects of river inflow on a reservoir and a stretch located downriver from a dam and reported P. maculatus as a typical species of riverine zones, primarily during the wet season, when the flow is higher. In contrast, Agostinho et al. (2007) found that $P$. maculatus, unlike other migratory species, predominated in the lacustrine zone of Lajeado Reservoir. The use of various aquatic macrohabitats by this species suggests its high habitat plasticity.

Except for $A$. aff. bimaculatus, O. hepsetus, and $H$. malabaricus, i.e., two water-column and one benthic species, respectively, the remaining species (all benthics) 
showed substrate preferences. The lower stretch of the Guandu River is homogeneous and has a low water quality (Lameira et al., 2010) because of human activities that have resulted in a predominantly silty bottom substrate, a lack of riparian cover, and low shoreline complexity. Tidal influence also contributes to increased sedimentation in this lower stretch. However, L. castaneus, T. striatulus, and H. littorale were capable of withstanding such unfavorable conditions. In particular, $H$. littorale has been reported to be able to breathe air, an adaptation that allows the exploration of extreme or altered habitats with low oxygen availability (Persuad et al., 2006).

The recent and remarkable hydrologic changes in the Guandu system, with the introduction of an additional water discharge of $160 \mathrm{~m}^{3} \mathrm{~s}^{-1}$ and the withdrawal of $47 \mathrm{~m}^{3} \mathrm{~s}^{-1}$, may have influenced habitat availability, among other physical constraints, most likely affecting fish distributions throughout the river. According to Poff (1997), each aquatic system has peculiar characteristics that act as filters to determine which species are apt to occupy the habitats, and the patterns of abundance and distribution are a result of the ways in which the species adjust to local environmental conditions. The strong fish-habitat relationship observed in this study suggests that hydraulic and substrate variables are important environmental filters affecting the Guandu River. Although our findings are specific to the Guandu River basin, the patterns of preferences observed may be consistent and transferable to other Neotropical river basins.

The precise description of habitat preferences of species through different parts of the life cycle is fundamental for protecting river fishes and facilitating their recovery (Brookes et al., 1983; Copp, 1990). We observed that the studied species had specific affinities for hydraulic and substrate variables and differed in abundance among the sampled stretches. The habitat preferences described here are an improvement over a subjective classification that associates a given species with a given habitat type, but further studies on this subject are needed to obtain a more detailed picture of habitat selection by fishes.

\section{Acknowledgments}

The study was funded by FAPERJ, Fundação Carlos Chagas de Amparo à Pesquisa do Estado do Rio de Janeiro, Proc. E-26/102.997/2011, Program "Cientista do Nosso Estado", to the last author. The first author received FAPERJ/ CAPES scholarships. ICMBio provided the license for fish collecting (Process. number 10.707). For encouragement and technical support the authors wish to express their gratitude to Dr. Francisco Martinez Capel, of Universidad Politécnica de Valencia/Spain.

\section{Literature Cited}

Agostinho, A. A., E. E. Marques, C. S. Agostinho, D. A. Almeida, R. J. Oliveira \& J. R. B. Melo. 2007. Fish ladder of Lajeado Dam: migrations on one-way routes? Neotropical Icththyology, 5: 121-130.

Araújo, F. G. \& L. N. Santos. 2001. Composition and structure of fish community in Laje's reservoir, RJ. Revista Brasileira de Biologia, 61: 563-576.

Araújo, F. G., C. C. Andrade, R. N. Santos, A. F. G. N. Santos \& L. N. Santos. 2005. Spatial and seasonal changes in the diet of Oligosarcus hepsetus (Characiformes, Characidae) in a Brazilian reservoir. Revista Brasileira de Zoologia, 65: 1-8.

Baltz, D. M., B. Vondracek, L. R. Brown \& P. B. Moyle. 1987. Influence of temperature on microhabitat choice by fishes in a California stream. Transactions of the American Fisheries Society, 116: 12-20.

Binder, W. 1998. Rios e Córregos, Preservar, Conservar, Renaturalizar. A Recuperação de Rios, Possibilidades e Limites da Engenharia Ambiental. Rio de Janeiro. SEMADS.

Boavida, I., J. M. Santos \& R. V. Cortes. 2006. Habitat use by native and stocked trout (Salmo trutta L.) in two northeast streams, Portugal. Bulletin Français de Pêche et Pisciculture, 382: 1-18.

Bovee, K. D. 1982. A guide to stream habitat analysis using the instream flow incremental methodology. U.S. Fish and Wildlife Service, Instream Flow Information Paper 12. FWS/OBS-82/26.

Bovee, K. D. 1986. Development and evaluation of habitat suitability criteria for use in the instream flow incremental methodology. U.S. Fish and Wildlife Service, Washington, D.C., Instream Flow Information Paper 21, Biological Report, 86.

Brookes, A., K. L. Gregory \& F. H. Dawson. 1983. An assessment of river channelization in England and Wales. The Science of the Total Environment, 27: 97-111.

Bührnheim, C. M. 2002. Heterogeneidade de habitats: rasos x fundos em assembleias de peixes de igarapés de terra firme na Amazônia Central, Brasil. Revista Brasileira de Zoologia, 19: 889-905.

Câmara, J. J. C., A. M. Rodrigues, E. C. Campos, R. A. Santos \& J. Mandelli. 1991. Pesca do tambiú Astyanax bimaculatus Linnaeus, 1758 (Characiformes, Characidae), com a utilização de redes de emalhar, na represa de Ibitinga, rio Tietê, Estado de São Paulo, Brasil. Boletim do Instituto de Pesca, 18: 51-60.

Casatti, L. 2005. Fish assemblage structure in a first order stream, southeastern Brazil: longitudinal distribution, seasonality, and microhabitat diversity. Biota Neotropica, 5: 1-9.

Casatti, L., F. Langeani \& R. M. C. Castro. 2001. Peixes de riacho do Parque Estadual Morro do Diabo, bacia do Alto Rio Paraná, SP. Biota Neotropica, 1: 1-15.

CBH - Guandu, Comitê de Bacia Hidrográfica do rio Guandu, 2007. Plano estratégico de recursos hídricos das bacias hidrográficas dos rios Guandu, da Guarda e Guandu Mirim: relatório síntese. Brasília: ANA (Agência Nacional de Águas); SONDOTÉCNICA.

Copp, G. H. 1990. Effect of regulation on $0+$ fish recruitment in the Great Ouse, a lowland river. Regulated rivers: Research \& Management, 5: 251-263.

DeGraaf, D. A. \& L. H. Bain. 1986. Habitat use and preferences of juvenile Atlantic salmon in two Newfoundland rivers. Transactions of the American Fisheries Society 115: 671-681.

Duarte, S. \& F. G. Araújo. 2001. Abundância relativa e distribuição de Loricariichthys spixii (Steindachner, 1882) (Siluriformes, Loricariidae) na represa de Ribeirão das Lajes, Rio de Janeiro, Brasil. Revista Brasileira de Zoologia, 18: 465-477. 
Hayes, J. W. \& I. G. Jowett. 1994. Microhabitat models of large driftfeeding brown trout in three New Zealand rivers. North American Journal of Fisheries Management, 14: 710-725.

Hostache, G. \& J. H. Mol. 1998. Reproductive biology of the neotropical armoureds catfish Hoplosternum littorale (Osteichthyes, Siluriformes) a synthesis steering the role of the floating bubble hest. Aquatic Living Resources, 11: 173-185.

Jowett, I. G. 1989. River hydraulic and habitat simulation, RHYHABSIM computer manual. Ministry of Agriculture and Fisheries, New Zealand Fisheries Miscellaneous Report 49.

Jowett, I. G. 2002. In-stream habitat suitability criteria for feeding inanga (Galaxias maculatus). New Zealand Journal of Marine and Freshwater Research, 36: 399-407.

Jowett, I. G. 2005. Computer software - HABPFR - version 2.0. New Zealand Foundation for Science Research and Technology and Regional Councils, New Zealand. Available from: http://www. jowettconsulting.co.nz/home/software / (12 September 2012).

Jowett, I. G. \& J. Richardson. 1995. Habitat preferences of common, riverine New Zealand native fishes and implications for flow management. New Zealand Journal of Marine and Freshwater Research, 29: 13-23.

Lameira, A. B., C. Renno, H. F. Motta, L. A. C. Lopes, M. Menegon, R. S. Oliveira, T. B. C. Barcellos, N. G. Zainer \& R. B. Prado. 2010. Diagnóstico e alternativas para a recuperação ambiental da bacia hidrográfica do rio Guandu (BHRG) - RJ: Embrapa Solos.

Lamouroux, N., H. Capra, M. Pouilly \& Y. Souchon. 1999. Fish habitat preferences in large streams of southern France. Freshwater Biology, 42: 673-687.

Leal, C. G., N. T. Junqueira \& P. S. Pompeu. 2011. Morphology and habitat use by fishes of the Rio das Velhas basin in southeastern Brazil. Environmental Biology of Fish, 90: 143-157.

Leonard, P. M. \& D. J. Orth. 1988. Use of habitat guilds of fishes to determine instream flow requirements. North American Journal of Fisheries Management, 8: 399-409.

Milhous, R. T., D. L. Wegner \& T. Waddle. 1984. User's guide to the physical habitat simulation system. United States Fish and Wildlife Service, Cooperative Instream Flow Group, Instream Flow Information Paper 11.

Milhous, R. T., M. A. Updike \& D. M. Schneider. 1989. Physical habitat simulation system reference manual-version II. U.S. Fish and Wildlife Service Instream Flow Information Paper 26. Biological Report 89(16).

Moyle, P. B. \& D. M. Baltz. 1985. Microhabitat use by an assemblage of California stream fishes: developing criteria for instream flow determinations. Transactions of the American Fisheries Society, 114: 695-704.

Murchie, K. J., K. P. E. Hair, C. E. Pullen, T. D. Redpath, H. R. Stephens \& S. J. Cooke. 2008. Fish response to modified flow regimes in regulated rivers: Research methods, effects and opportunities. River Research and Applications, 24: 197-217.

Oliveros, O. B. \& L. M. Rossi. 1991. Ecologia trófica de Hoplias malabaricus (Pisces: Erythrinidae). Revista de la Asociación de Ciencias Naturales de Litoral, 22: 55-68.

Persaud, D. I., I. W. Ramnarine \& J. B. R. Agard. 2006. Ontogeny of the alimentary canal and respiratory physiology of larval Hoplosternum littorale (Hancock, 1828): an intestinal airbreathing teleost. Environmental Biology of Fishes, 76: 37-45.
Petts, G. E. 1984. Impounded rivers: perspectives for ecological management. New York, John Wiley \& Sons.

Petts, G. E. 1985. Time scales for ecological concern in regulated rivers. Pp. 257-266. In: Craig J. F \& J. B. Kemper (Eds.). Regulated Streams: Advances in Ecology. New York: Plenum Press.

Pinto, B. C. T., F. G. Araújo \& R. M. Hughes. 2006. Effects of landscape and riparian condition on a fish index of biotic integrity in a large southeastern Brazil river. Hydrobiologia, 556: 69-83.

Poff, N. L. 1997. Landscape filters and species traits: towards mechanistic understanding and prediction in stream ecology. Journal of the North American Benthological Society, 16: 391-409.

Santos, A. B. I., B. F. Terra \& F. G. Araújo. 2010. Fish assemblage in a dammed tropical river an analysis along the longitudinal and temporal gradients from river to reservoir. Zoologia, 27: 732-740.

Sheppard, J. D. \& J. H. Johnson. 1985. Probability-of-use for depth, velocity, and substrate by subyearling coho salmon and steelhead in Lake Ontario tributary streams. North American Journal of Fisheries Management, 5: 277-282.

Suzuki, H. I., A. A. Agostinho \& K. O. Winemiller. 2000. Relationship between oocyte morphology and reproductive strategy in loricariid catfishes of the Parana River, Brazilian Journal Fish Biology, 57: 791-807.

Teresa, F. B. \& L. Casatti. 2013. Development of habitat suitability criteria for Neotropical stream fishes and an assessment of their transferability to streams with different conservation status. Neotropical Ichthyology, 11: 395-402.

Terra, B. F., A. B. I. Santos \& F. G. Araújo. 2010. Fish assemblage in a dammed tropical river: an analysis along the longitudinal and temporal gradients from river to reservoir. Neotropical Ichthyology, 8: 599-606.

Vadas, R. L. Jr. \& D. J. Orth. 2000. Habitat use of fish communities in a Virginia stream system. Environmental Biology of Fishes, 59: 253-269.

Vadas, R. L. Jr. \& D. J. Orth. 2001. Formulation of Habitat Suitability Models for stream fish guilds: do standard methods work? Transactions of the American Fisheries Society, 130: 217-235.

Vono, V., L. G. M. Silva, B. P. Maia \& H. P. Godinho. 2002. Reproductive biology of three simpatric species of Neotropical fishes: Pimelodus maculatus Lacépède (Siluriformes, Pimelodidae), Leporinus amblyrhynchus and Schizodon nasutus Kner (Characiformes, Anostomidae) from the newly formed Miranda Reservoir, High Paraná Basin. Revista Brasileira de Biologia, 19: 819-826.

Yu, S. L. \& T. W. Lee. 2002. Habitat Preference of the Stream Fish, Sinogastromyzon puliensis (Homalopteridae). Zoological Studies, 41: 183-187.

Submitted September 19, 2012 Accepted July 31, 2013 by Fabrício Teresa Published December 27, 2013 